Bartın Üniversitesi

Eğitim Fakültesi Dergisi

Cilt 5, Sayı 3, s.893-907, Ekim 2016

BARTIN - TÜRKIYE

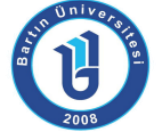

ISSN: 1308-7177
BartinUniversity

Journal of Faculty of Education

Volume 5, Issue3, p. 893-907, 0ctober2016

BARTIN - TURKEY

Doi: $10.14686 /$ buefad.v5i3.5000204382

\title{
The Examination of Views of Parents about the Web-Based Performance Evaluation Program in Science Teaching Process
}

Hasan BAKIRCI, Yrd. Doç. Dr.,Yüzüncü Yıl Üniversitesi, Eğitim Fakültesi, hasanbakirci09@gmail.com

Yılmaz KARA, Yrd. Doç. Dr., Bartın Üniversitesi, Eğitim Fakültesi, yilmazkaankara@yahoo.com

Salih ÇEPNi, Prof. Dr., Uludağ Üniversitesi, Eğitim Fakültesi, cepnisalih@yahoo.com

\begin{abstract}
The research was aimed to reveal the views of parents on web-based performance evaluation program. The case study method was adopted for this study. The research was conducted in the central district of Trabzon province during the fall semester of 2014-2015 academic years. A questionnaire was administered to three hundred parents and face-to-face interviews were conducted with 10 of those parents. The obtained data was analyzed through descriptive and content analysis. The majority of the parents were found to be satisfied that they could see how their children were evaluated through the different kind of performance activities which were used as an assessment and evaluation instrument, and scores of their children achieved in those activities. However, the implementation of the study with a quite limited parental participation caused the study to remain incapable of reflecting the views on this subject sufficiently. It was recommended that web-based program should be administered to a larger sample.
\end{abstract}

Keywords: science education, educational technology, alternative assessment

\section{Fen Öğretimi Sürecinde Velilerin Web Tabanlı Performans Değerlendirme Programı Hakkındaki Görüşlerinin İncelenmesi}

Öz: Bu çalışma velilerin web tabanlı performans değerlendirme programı hakkındaki görüşlerini ortaya çıkarmayı amaçlamaktadır. Çalışmada özel çalışması durum yöntemi benimsenmiştir. Araştırma, Trabzon il merkezinde 2014-2015 akademik yılı güz döneminde yürütülmüştür. Üç yüz veliye anket uygulanırken, bu velilerden 10 tanesi ile yüz yüze görüşmeler yapılmıştır. Anket ile elde edilen veriler betimsel analiz ve içerik analizi ile analiz edilmiştir. Çalışmaya katılan velilerin büyük çoğunluğunun öğrencilerin bir ölçme ve değerlendirme aracı olarak kullanılan faklı performans aktiviteleri ile nasıl değerlendirildiklerini ve bu aktivitelerde aldıkları notları görebilmelerinden tatmin oldukları bulunmuştur. Ancak çalışmanın oldukça sınırlı bir veli katılımıyla yürütülmüş olması bu yönündeki görüşleri tam olarak yansıtmada yetersiz kalmıştır. Web tabanlı programın daha geniş örneklem üzerinde yürütülmesi önerisinde bulunulmuştur.

AnahtarKelimeler: fen eğitimi, eğitim teknolojileri, alternatif ölçme

\footnotetext{
This manuscript was produced through the project (109K571) supported by TUBITAK.
} 


\section{INTRODUCTION}

The modern assessment and evaluation methods advocate that alternative assessment methods should be more included in the assessment and evaluation process. The one of the most effective way of evaluating the skills, performances and learning processes is alternative assessment since traditional assessment methods are mostly focused on student cognition (Wyse \& Albano, 2015). The alternative assessment methods do not evaluate students only in terms of knowledge and achievement at the end of the educational processes but also in terms of skills and attitudes during the educational activities through group works, project works, inclass performance activities, the interactions of students with peers, and performance tasks. In alternative assessment method, documents including the in class activities, reports, posters, presentations, and assignments of students are collected in the student product file whereby the improvement in the student performance can be evaluated in a more detailed and flexible manner (Butler \& McMunn, 2006; Çoruhlu, Nas ve Çepni, 2009; Jones \& Inglis, 2015).

The conducted studies about educational measurement and assessment have little or no mention to introduce alternative assessment approaches and techniques to parents and inform them about their tasks and responsibilities (Rutkowski, Rutkowski \& Plucker, 2015). In addition, alternative assessment understanding requires parents to become more responsive on tasks and responsibilities (Milli Eğitim Bakanlığı [MEB], 2004, 2013). The strength of the education could be improved by the active participation of parents in the process, the opportunity to observe the improvements of their own children, and the possibility of receiving rapid feedback (Çepni, Ayvacı ve Bakırcı, 2012; Grossman, Cohen, Ronfeldt \& Brown, 2014). The inclusion of teachers in this process may ensure the intended and desired teacherstudent-parent interaction and bring them one step closer to the success (Dickenson, Gilmore, Price \& Bennett, 2014; Sabry \& Baldwin, 2003).

The web-supported programs could be used in order to ensure more active participation of the parents in the alternative assessment and evaluation process. When the advantages of web-supported programs are considered for the educational evaluation, webbased assessment can more enable parents to be involved in the process of the implementation and evaluation of the alternative assessment and evaluation approaches. The review of international literature demonstrates that studies mostly deal with the development of e-portfolio systems and web-based programs for peer assessment and rubric development. These studies reported that the alternative assessment and evaluation methods and techniques can be implemented in a web-based manner, and these kinds of methods and techniques had positive effects on students and parents (Barrett, 2006; Gathercoal, Love, Bryde \& McKean, 2002; Lin, Liu \& Yuan 2001).

While some studies indicated that such methods and techniques positively affect the learning, academic achievement, and attitude towards relevant subjects, some of the other studies focus on the implementation of assessment and evaluation which is one of the inevitable components of education in a web-based fashion (Callı, Torkul ve Taşbaşı, 2003; Çelik, 2006; Karakaya, 2002). These studies mostly concentrate on web-based test development and online test applications. On the other hand, it is seen that there is no system has been included evaluation forms as rubric, control lists, and graded scales can be developed and implemented by teachers in a flexible manner, acquired data can be stored, such data can be used for monitoring student development, teachers, students and parents can be included in the same evaluation system, feedbacks can be provided for teachers, students, and parents, and the developed evaluation form can be shared with others teachers has been designed and implemented, and the effects of this kind of a system on the usage of alternative assessment and evaluation have not been investigated (Birgin, 2010). 
The preparation of web-based program allowing the preparation and implementation of alternative evaluation forms in a web-based fashion to introduce a new dimension and perspective in the matter of preparing and implementing these kinds of evaluation forms and incorporating parents in the system. The review of web pages prepared for the assessment shows that such web addresses can be used during the coverage of just a particular unit or subject of only one course in general. It is interesting that there is no web based environment aimed the preparation and/or implementation of scales for scoring assessment and evaluation or performance evaluation. This authentic value of the present study may provide important knowledge for the researchers and enable parents to participate in the assessment and evaluation process more effectively (Birgin, Tutak ve Türkdoğan, 2009; Hurley \& Murphy, 2015; Kearns, Kleinert, Thurlow, Gong \& Quenemoen 2015).

It is necessary to determine the degree to which a web-based program can include students and parents in the evaluation process, calculate average score by collecting all the evaluations carried out, and allow feedbacks in the light of the data acquired meets the requirements of parents, and what kind of changes are needed in the program in development process (Varsavsky \& Rayner, 2014; Wellman, 2005). In this regard, this study aimed to determine the views of parents about web-based performance evaluation program.

\section{METHOD}

\subsection{Research design}

The case study method was adopted for this study since the case study method allows studying a particular aspect of a problem deeply and in a short time. By its nature, the case study method enables a problem to concentrate on a particular case, and allows the use of different data collection techniques together (Çepni, 2010; Ekiz, 2013).

\subsection{Sample}

The study was conducted with 300 parents in the central district of Trabzon province during the fall semester of the 2014-2015 academic years. First, a questionnaire was administered to 300 (117 female) parents. Then, face-to-face interviews were conducted with 10 of those 300 parents. The active use of web-based performance evaluation program was taken into account while recruiting the parents for the interview procedures. The demographic characteristics of the study group are given in the table 1.

Table 1

The Demographic Characteristics of Participant Parents

\begin{tabular}{|c|c|c|c|c|c|}
\hline Educational Status & $f$ & $\%$ & Profession & $f$ & $\%$ \\
\hline Primary School & 100 & 33.3 & Civil Servant & 90 & 30.1 \\
\hline High School & 110 & 36.6 & Self-Employed & 85 & 28.3 \\
\hline University & 90 & 30.1 & Worker & 67 & 22.3 \\
\hline Total & 300 & 100 & Other & 58 & 19.3 \\
\hline Income Level & $f$ & $\%$ & Age Range & $f$ & $\%$ \\
\hline $500-1000$ & 45 & 15 & 30 to 34 years old & 10 & 3.4 \\
\hline $1000-1500$ & 75 & 25 & 35 to 39 years old & 64 & 21.4 \\
\hline $1500-2000$ & 80 & 26.6 & 40 to 44 years old & 92 & 30.6 \\
\hline $2000-2500$ & 70 & 23.4 & 45 to 49 years old & 78 & 26 \\
\hline 2500 and over & 30 & 10 & 50 and older & 56 & 18.6 \\
\hline
\end{tabular}

The demographic characteristics of parents who were subjected to interview are provided in the table 2 . 
Table 2

The Demographic Characteristics of the Parents Participating in the Interview

\begin{tabular}{lcccccc}
\hline & Education & Occupation & Age & Computer & Internet at home & Computer use \\
\hline $\mathbf{P}_{\mathbf{1}}$ & Primary School & Self-Employed & 45 & Available & Available & Good \\
$\mathbf{P}_{\mathbf{2}}$ & Primary School & Other & 38 & Available & Available & Good \\
$\mathbf{P}_{\mathbf{3}}$ & Primary School & Workman & 52 & Available & Available & Good \\
$\mathbf{P}_{\mathbf{4}}$ & High School & Civil Servant & 35 & Available & Available & Good \\
$\mathbf{P}_{\mathbf{5}}$ & High School & Workman & 48 & Available & Available & Good \\
$\mathbf{P}_{\mathbf{6}}$ & High School & Other & 51 & Available & Available & Good \\
$\mathbf{P}_{\mathbf{7}}$ & University & Civil Servant & 37 & Available & Available & Good \\
$\mathbf{P}_{\mathbf{8}}$ & University & Civil Servant & 40 & Available & Available & Good \\
$\mathbf{P}_{\mathbf{9}}$ & University & Civil Servant & 39 & Available & Available & Good \\
$\mathbf{P}_{\mathbf{1 0}}$ & University & Self-Employed & 46 & Available & Available & Good
\end{tabular}

\subsection{Data collection tools}

The questionnaire and semi-structured interviews were administered for data collection. The items of the questionnaire categorized in terms of the functional features of web-based program, the technical features of web-based program, the advantages provided by the use of web-based program, and the problems encountered in the use of web-based program. For the semi-structured interview form, researchers determined 10 questions at the beginning. However, the number of questions was decreased to five after the consideration of the expert opinions. The parents were required an appointment for the interviews. The interviews were carried out at work places or houses of the participants at times deemed suitable by the participants. The questions included in the interview form were about the advantages of prepared web-based program, comparison of educational evaluation process conducted by program with paper-pencil tests, personal opinions on program, deficiencies of the program, and suggestions for eliminating the deficiencies.

\subsection{The validity and reliability of the data collection tools}

The most important point requiring highest amount of attention in a questionnaire is the content validity of the questionnaire. Turning to expert opinion is known to be the most scientific way of improving the content validity of a questionnaire. The opinions of three experts in the field of science education were taken in order to ensure the content validity of the questionnaire employed in this study. The reliability of the questionnaire was found to be 0.81 through Cronbach's Alpha method. This value provides an important clue in regard to the reliability of the questionnaire (Çepni, 2010; Ekiz, 2013).

The member checking, peer debriefing, and expert review procedures were performed in order to improve the validity the interview. The interviews were conducted face-to-face with the participating parents. The data were recorded via voice recorder during the interviews. Then, the voice records were transcribed by researchers. The member checking was performed in order to eliminate the deficiencies and misunderstandings about those data and check points whose inclusion or removal was requested by the participants. In addition, the opinions of two expert specialized in the field of qualitative research (apart from the researchers) were taken in regard to the coding in the data analysis process. The correspondence between the coders was taken into consideration. It is generally emphasized that voluntariness of participants is important for ensuring the validity and reliability of the study (Ekiz, 2013; Yıldııım \& Şimşek, 2005). 


\subsection{Procedure}

Before beginning to use the web based alternative assessment program, each participant parents were given an introductory course. During the course, the parents were provided theoretical information on traditional and alternative assessment and evaluation. In addition, parents were introduced "parent-student guide material" which was developed by the project team. The "web-based performance evaluation program" was introduced to parents after having basic theoretical understanding about alternative assessment. After the course, the parents were assigned guide and monitoredin six months through a project member. Finally, questionnaires and interviews were administered in order to collect the views of parents about Web-Based Performance Evaluation Program.

\subsection{Data Analysis}

Quantitative data were collected through a questionnaire, and qualitative data were acquired by means of semi-structured interviews. The SPSS package program was used for analyzing the data acquired from the questionnaire. The data acquired from the questionnaire were presented in tables containing frequency and percentage values. Descriptive analysis and content analysis were used for analyzing the acquired interview data. The reason for adopting descriptive analysis is that it summarizes and interprets the data based on the themes determined beforehand, and includes direct quotations in order to reflect the views of the individuals subject to interview or observation in a striking fashion (Çepni, 2010; Yıldırım \& Şimşek, 2005). In addition, content analysis was conducted in order to reveal the concepts and themes going unnoticed in the descriptive analysis, and subject the data to a deeper analysis (Ekiz, 2013; Yıldırım \& Şimşek, 2006). The interview data that were transcribed after they were recorded electronically were read again and again so that data remaining outside the scope of the study were removed whereby data reduction was conducted. Then, it was preceded to the coding stage. Coding was performed in accordance with the common opinions of three coders. An attempt was made to make it easier for readers by forming matrixes out of the themes and codes acquired.

\section{FINDINGS}

Based on the questionnaire results, the views of parents about the technical and functional characteristics of the program as well as the advantages it provides and the problems encountered in it are given below.

Table 3

The Views of the Parents Using the Web Page and Participating in the Questionnaire Concerning the Functional Features of the Web-Based Program

\begin{tabular}{lll}
\hline The functional characteristics of the web-based program & $\mathrm{f}$ & $\%$ \\
\hline Web-Based Program fulfills functions correctly. & 210 & 70 \\
Web-Based Program fulfills functions reliably. & 154 & 51 \\
The functional explanations and instructions in the program are sufficient. & 145 & 48 \\
\hline
\end{tabular}

The examination of the table 3 shows that $70 \%$ of the parents using the web page, which was created within the scope of the study, and participating in the questionnaire think that the web-based program fulfills functions correctly. The $51 \%$ of the participants think that the program fulfills functions reliably. The $48 \%$ of the participant parents think that its functional explanations and instructions are sufficient. 
Table 4

The Views of the Parents on Technical Features of the Web-Based Program

\begin{tabular}{lll}
\hline The technical features of the web-based program & $\mathbf{f}$ & $\%$ \\
\hline Web-Based Program has reliable technical features. & 156 & 52 \\
Web-Based Program has a properly operating database. & 258 & 86 \\
Web-Based Program has rapid accessibility. & 201 & 67 \\
Web-Based Program operates correctly and non-erroneously. & 185 & 67 \\
Web-Based Program is easy to use. & 177 & 64 \\
Web-Based Program has a plain and clear language. & 171 & 62 \\
\hline
\end{tabular}

The examination of the table 4 shows that $86 \%$ of the parents using the web page, which was created within the scope of the study, and participating in the questionnaire stated that the web-based program had a properly operating database, $67 \%$ said that the web-based program had rapid accessibility and operated non-erroneously. On the other hand, 52\% mentioned that the web-based program had reliable technical features, and $64 \%$ told that the web-based program was easy to use.

Table 5

The Views of the Parents on Advantages Provided by the Web-Based Program

\begin{tabular}{lll}
\hline Opinions on the advantages provided by the use of website & $\mathbf{f}$ & $\mathbf{\%}$ \\
\hline Grades can be learnt more rapidly and easily. & 212 & 71 \\
Faster evaluation is possible. & 191 & 64 \\
Allows seeing the evaluation criteria. & 270 & 90 \\
A comparison can be made by seeing all grades. & 205 & 68 \\
Direct communication can be established between students, teachers, and parents. & 286 & 95 \\
Reminds us upcoming events and developments & 262 \\
Improves computer usage skills, too. & 95 \\
Objective evaluation is possible thanks to the Web-Based Program. & 32 \\
\hline
\end{tabular}

The examination of the table 5 reveals that $95 \%$ of the parents using the web page, which was created within the scope of the study, and participating in the questionnaire think that thanks to the Web-Based Program, direct communication can be established between students, teachers, and parents, $90 \%$ think that it allows seeing the evaluation criteria. On the other hand, $71 \%$ stated that they could learn the grades more rapidly and easily thanks to the web-based program while $64 \%$ told that the web-based program enabled faster evaluation. While $68 \%$ of the parents think that the web-based program allows making comparison by seeing all grades, $62 \%$ think that it allows an objective evaluation. $32 \%$ think that the webbased program improves computer usage skills.

Table 6

The Views of the Parents onDifficulties Encountered during the Usage of the Web-Based Program

\begin{tabular}{lll}
\hline Opinion on problems experienced during the use of the website & $\mathbf{f}$ & $\mathbf{\%}$ \\
\hline Web-Based Program must not allow other students to see grades. & 120 & 40 \\
An informative video about the use of the program must be put on the home page. & 245 & 82 \\
Sample activities conducted must be added to the Web-Based Program. & 280 & 93 \\
Sample project and performance subjects must be added to the Web-Based Program. & 272 & 91 \\
Subjects and acquisitions must be added to the Web-Based Program. & 208 & 69 \\
\hline
\end{tabular}


The examination of the table 6 shows that $82 \%$ of the parents using the web page, which was created within the scope of the study, and participating in the questionnaire think that there is no informative video about the site and its usage, $93 \%$ think that there is no sample activity, $40 \%$ said that grades are seen by other students. $69 \%$ stated that subjects and acquisitions were not provided in the site while $91 \%$ made mention of the problems related to the deficiency of sample project and performance subjects.

This section presents the data acquired within the framework of research problems through an analysis from the perspective of parents. The data acquired through interviews were subjected to content analysis. Codes were formed and matrixes were constituted in regard to each question. To make those codes easier to understand, the data obtained through interviews were analyzed descriptively. The figure 1 presents the codes emerging in regard to each question in the parent interview. The parents participating in the interview were represented as $\mathrm{P}_{1}, \mathrm{P}_{2}, \mathrm{P}_{3}, \ldots \ldots . . \mathrm{P}_{10}$.

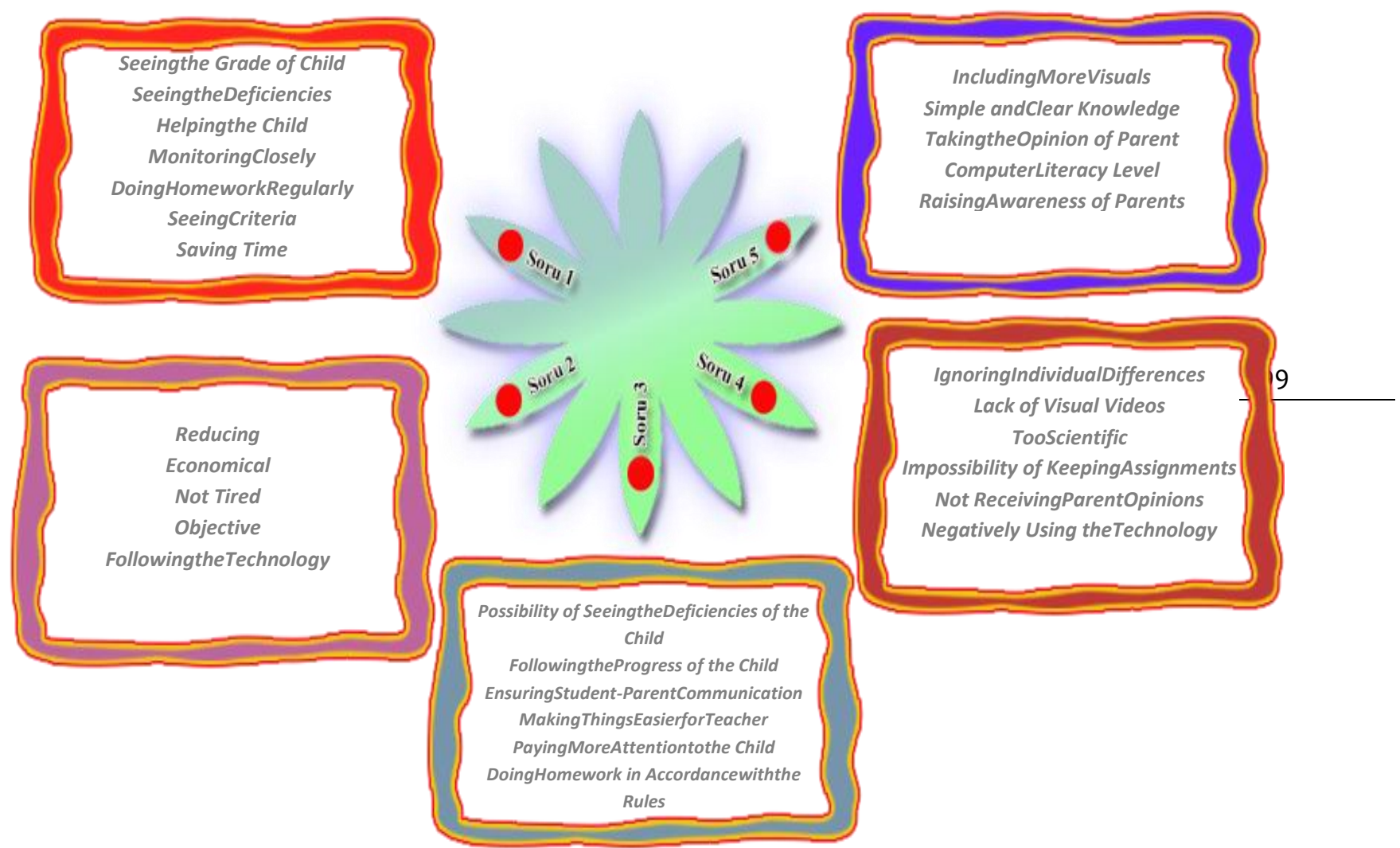

Figure 1. Codes obtained through the interviews conducted with parents concerning the webbased program

Figure 1 gives the codes obtained through the interviews conducted with parents concerning the web-based program used by them. With regard to the advantages provided by the web-based program, parents touch on learning the grade of the child, seeing the deficiencies, helping the child, monitoring the child closely, doing homework closely, saving time, learning the interest of the child in the course, and seeing the evaluation criteria.

All of the parents participating in the study delivered common opinions about the codes of learning the grade of the child, saving time, seeing the deficiencies of the child, and 
seeing the evaluation criteria. The $\mathrm{P}_{5}$ was stated that "Thanks to this site, I can learn the grade of my child at my home or work place easily without going to the school. In addition, I try to help my child as much as possible by seeing how my child is evaluated by the teacher". The 3 of the parents participating in the interview $\left(P_{2}, P_{5}, P_{8}\right)$ stated that the web-based program encouraged students to do homework regularly. The $\mathrm{P}_{8}$ was mentioned that "The fact that my child and I used this site gave me an opportunity to follow the science course of my child regularly. I saw that my child did his homework for the science course regularly. This made me very happy".

During the interview, parents were asked to compare the evaluation made by use of paper and pencil with the evaluation made through the web-based program. Parents lay emphasized on such issues as deforestation, being economical, not being too tired, objectivity, and following the technology. The 5 of the parents participating in the interview $\left(P_{1}, P_{4}, P_{5}, P_{7}\right.$, and $P_{8}$ ) stated that the prepared web-site would reduce deforestation, though a little. $P_{1}$ expressed that as "Thanks to this site, teachers will use paper and pencil less. Thus, our forests will be cut less, so our forests will not be eradicated in a short time". On the other hand, the 4 of the parents $\left(P_{2}, P_{3}, P_{7}\right.$, and $\left.P_{10}\right)$ said that the evaluation made by paper and pencil was more economical. The $\mathrm{P}_{7}$ was explained that as "This website is more economical than the evaluation by paper and pencil. This is because paper and pencil will not be needed much thanks to this site. Thanks to this site, students will be evaluated objectively. The collective use of this site by students, parents, and teachers make this site nicer". The 5 parents participating in the interview $\left(P_{2}, P_{3}, P_{5}, P_{6}, P_{8}\right)$ mentioned that the site gave an opportunity to follow the technology. The $\mathrm{P}_{8}$ was pointed out that as "I did not think the technology would appear in every field of our life so much. Thanks to this site, I can follow the science and technology course of my child, which I really appreciate. It would be better if this site was arranged to cover other courses. Then, we would have more opportunity to follow the technology".

The general opinions of parents about the web-based program were asked. It was seen that a great majority of the parents had positive opinions about the web-based program. In this matter, parents laid emphasis on such codes as seeing the deficiencies, following the progress of the student, ensuring the student-parent communication, making things easier for the student, paying more attention, doing homework in accordance with the rules, and being knowledgeable. It was observed that parents frequently made mention of such codes as seeing the deficiencies of the child, following the progress of the child, and ensuring the communication between children and parents. The $\mathrm{P}_{9}$ was underlined that as "Thanks to this website, I can see the deficiencies of my child in the science and technology course, and I can follow the achievement status of my child". On the other hand, some parents participating in the study $\left(P_{1}, P_{6}, P_{10}\right)$ delivered the opinion that this site made things easier for teachers. The $\mathrm{P}_{10}$ was highlighted that as" This site makes things easier for teachers. This is because there is a computer in most of the houses. Teachers are very comfortable now because they do not have to prepare, move and keep grade books where the evaluation grades of children are written".

The deficiencies of the web-based program were asked to parents. In response, parents stated that the web-based program ignores individual differences, certain problems may emerge in terms of the delivery of assignments, there may be problems for the parents with insufficient computer usage level, the web-based program is too scientific, and technology may be used by students negatively. All parents stated that there might be problems for the parents with insufficient computer usage levels. The opinions of $\mathrm{P}_{4}$ on this subject are as follows: 
"... This site is well-designed, but I do not think that some parents who do not know how to use computer will enter in this site regularly by using passwords. I think the parents using this site must have computer knowledge to a particular degree ..."

Some of the parents $\left(P_{1}, P_{5}, P_{7}\right)$ regarded lack of a section where students could keep and store their assignments in the system as a deficiency. The $P_{1}$ was mentioned that as "This site is good, but I see that it has certain deficiencies. One such deficiency is that the site is difficult to use, and is lack of a section where the performance assignments of my child can be kept and seen". The $\mathrm{P}_{4}$ told that the theoretical information in the site was too scientific, and it as difficult for parents to understand such information. The $\mathrm{P}_{4}$ was pointed that as "I have difficulty in understanding some subjects provided in the site. I think I have difficulty because an academic knowledge is used there. I think it would be better if it was provided in the language used by us".

During the interview, an attempt was made to learn the suggestions of parents for removing the deficiencies of the web-based program. In this regard, the parents suggested that more visuals should be included, the opinions of parents should be received, the computer literacy levels of parents should be improved, and awareness of parents should be raised under the guidance of teachers. One of the suggestions put forward by $\mathrm{P}_{8}$ on this subject is as follows:

"... This site is good in general, but I think it is visually weak. I think it would have been nicer if the opinions of parents had been taken while forming that site ..."

On the other hand, some parents stated that not every parent could use that site. The opinions of $\mathrm{P}_{1}$ on this subject are as follows:

"... Since many parents do not have satisfactory computer literacy levels, it is clear that such parents will not be able use the site adequately and learn the statuses of their children ..."

Some parents (e.g. $\mathrm{P}_{4}, \mathrm{P}_{8}$ ) delivered the opinion that the information provided in regard to the alternative assessment and measurement provided in the website was too scientific. So, parents had difficulty in understanding such information and provided in a clearer knowledge.

\section{DISCUSSION and CONCLUSION}

The examination of the obtained findings reveals that parents have quite positive opinions concerning the web-based performance evaluation program. On the other hand, some parents stated that there were some deficiencies in terms of the implementation process, design, and usability of the web-based performance evaluation program, and made some suggestions for the removal of such deficiencies.

A great majority of the parents underlined that the web-based program had sufficient functional features. The participant parents stated that the program was sufficient about explanations, instructions, and accessibility which were among the functional features of the program. Furthermore, the parents indicated that the web-based program fulfilled its functions reliably. The fact that the parents provided specific information about the operating process and applications of the program implies that the parents participating in the study used the web-based program regularly. This situation demonstrates the willingness of the parents to know and use effectively the variables that are influential on the achievements of their children. In addition, when the analysis of the data acquired from the parents participating to the interview, it was inferred that the result of parents need to use the program much more. Based on the literature review, it can be said that the results of the present study show similarity with those of many other studies in that web-based programs are accepted by their target groups to a great degree (Callı, et al., 2003; Chang, Liang \& Chen, 2012; Saprıatı \& Zuhaırı, 2010; Wyse \& Albano, 2015). 
The participant parents indicated positive opinions about the technical features of the web-based program. The parents stated that the database of the web-based program worked properly. In addition, some of them emphasized that the program had been designed in such a way that it would provide proper, non-erroneous, and rapid access. This may explained by the fact that the program was for just the science and technology course, practical, and noncomplicated. The findings of many studies reveal that the web-sites designed to be practical, easy, and intended for a particular purpose are frequently used by their users (Fan, Wang \& Wang, 2011). Moreover, parents stated that the program was easy to use. Furthermore, parents mentioned that the language used in the program was plain and clear. The participant parents had quite positive opinions about the advantage provided by the web-based program. The vast majority of the parents emphasized that the web-based program ensured the communication between teachers, students, and parents, and was quite beneficial in terms of seeing the manner of evaluation of the child as well as exam dates and assignment delivery dates. This is parallel with the results of many studies conducted (Callı, et al., 2003; Çelik, 2006; Eyal, 2012). On the other hand, more than half of the parents stated that the program provided an objective evaluation. The parents indicated that the program allowed them to send messages to the teacher and see the messages of other parents. The fact the teacher replied the messages coming from parents and students shows that the web-based program improves communication. The examination of the data acquired from the questionnaire and the interview reveals that parents could see the manner of evaluation of their children and they were satisfied with that process. This result is partly attributed to the fact that evaluation criteria are seen by parents and students other than the teacher and participatory evaluation is conducted.

As a consequence, it can be concluded that parents can learn the grades of their children more rapidly and easily through the web-based program which is also advantageous in terms of monitoring students. With regard to the problems encountered during the use of the web-based program, parents stated that the sample activities should be added to the webbased program and an informative video about the usage of the program. The resultswere in parallel with the conclusion and recommendations sections of the studies conducted in the past (Fan, Wang \& Wang, 2011; Lau, Hong, Lau, \& Usop, 2012).

Based on the findings obtained from this study, the following recommendations are put forward: If the assessment and evaluation process is supported by the web-based program and teachers, students, and parents (stakeholders of the educational process) participate in this process, a fairer standard of judgment may be obtained at the end of the education period. However, the implementation of the study with the participation of quite a limited number of participants causes a failure in exactly reflecting the views in this matter. The implementation of this web-based program on a larger sample may enable the views on this subject to be revealed more clearly. The roles of the parents play in the assessment and evaluation process for them may contribute to the program development process.

Although a great majority of the parents participating in the study could rapidly and reliably see, thanks to the web-based program, how their children were evaluated, what kinds of performances were employed as measurement tools, and which scores their children achieved in the relevant activities, some parents stated that they could not use related software rapidly and effectively. This situation reveals the importance of technology literacy levels and educational statuses of parents. The reason for failure of parents in using the webbased program effectively should be determined, and the educational material prepared for educating parents should be revised and put into a version which would enable higher number of parents to use web-based programs effectively. 
The most of the participant parents had the opportunity that the design of the program whereby web software is provided is satisfactory. However, some problems and additional requests are observed in the findings acquired from the questionnaire and the interview. Based on such requests, necessary arrangements should be made by taking into account the goals of the web software. The ways of integrating parents into the educational process (evaluation stage in particular) should be searched and indicated through different studies. Similar software should be generalized within the scope of Fatih Project, which has started to be used in national education system under the leadership of the Ministry of National Education. Parents should be included in this system, too.

\section{REFERENCES}

Barrett, H. (2006). Using Electronic Portfolios for Formative/Classroom-based Assessment. Connected Newsletter, 13 (2), 4-6.

Birgin, O. (2010). 4-5.Sınıf matematik öğretim programında öngörülen ölçme ve değerlendirme yaklaşımlarının öğretmenler tarafından uygulanabilirliği. Yayımlanmamış Doktora Tezi, Karadeniz Teknik Üniversitesi Fen Bilimleri Enstitüsü, Trabzon.

Birgin, O., Tutak, T. ve Türkdoğan, A. (2009). Primary school teachers' views about the new Turkish primary school mathematics curriculum. E-Journal of New World Sciences Academy, 4(2), 270-280.

Bulut, i. (2006). Yeni ilköğretim birinci kademe programlarının uygulamadaki etkinliğinin değerlendirilmesi.Yayımlanmamış Doktora Tezi, Fırat Üniversitesi Fen Bilimleri Enstitüsü, Elazığ.

Butler, S. M., \& McMunn N. D. (2006). A teacher's guide to classroom assessment: Understanding and using assessment to improve student learning. First Edition, San Francisco :Jossey-Bass.

Callı, I.,Torkul, O. ve Taşbaşı, N. (2003). İnternet destekli öğretimde kullanılmak üzere web erişimli veri tabanı yönetim sistemiyle ölçme ve değerlendirme sistemi Tasarımı. The Turkish Online Journal of Educational Technology, 2 (3), 13.

Chang, C., Liang, C. \& Chen, Y. (2012). Is learner self-assessment reliable and valid in a webbased portfolio environment for high school students? Computer \& Education, 60(1), 325-334.

Çelik, Z., (2006). Web Tabanlı Otomasyon ve Ölçme Değerlendirme Yönetim Sistemi : KTU Fatih Eğitim Fakültesi Örneği, Yüksek Lisans Tezi, Fen Bilimleri Enstitüsü, Karadeniz Teknik Üniversitesi, Trabzon.

Çepni, S. (2010). Araştırma ve proje çalışmalarına giriş. Celepler Matbaacılık, 5. Baskı, Trabzon.

Çepni, S., Ayvacı, H. Ş. ve Bakırcı, H. (2012). Veli rehber materyalinin yapılandırmacı yaklaşım içinde fen ve teknoloji öğretimine etkileri üzerine bir ön çalışma. Milli Eğitim Dergisi, Sayı: 195, 131-145. 
Çoruhlu, T. Ş., Nas, S. E. ve Çepni, S. (2009). Fen ve teknoloji öğretmenlerinin alternatif ölçme değerlendirme tekniklerini kullanmada karşılaştıkları problemler: Trabzon Örneği. Yüzüncü Yıl Üniversitesi, Eğitim Fakültesi Dergisi, (1)1, 122-141.

Dickenson, T., Gilmore, J. , Price, K., \& Bennett, H. (2014). Investigation of science inquiry items for use on an alternate assessment based on modified achievement standards using cognitive lab methodology. Journal of Special Education, 47(2), 108-120.

Ekiz, D. (2013). Eğitimde araştırma yöntem ve metotlarına giriş: Nitel nicel ve eleştirel kuram metodolojileri. Ankara: Anı Yayıncılık.

Eyal, L. (2012). Digital Assessment Literacy-the Core Role of the Teacher in a Digital Environment, Educational Technology \&Society, 15 (2), 37-49.

Fan, Y., Wang, T. \& Wang, K. (2011). A web-based model for developing assessment literacy of secondary in-service teachers.Computers \& Education, 75, 1727-1740.

Gathercoal, P., Love, D., Bryde, B., \& McKean, G., (2002). On Implementing Web-Based Electronic Portfolios. Educause Quarterly, 2, 2-37.

Grossman, P., Cohen, J., Ronfeldt, M., \& Brown, L. (2014). The test matters: The relationship between classroom observation scores and teacher value added on multiple types of assessment. Educational Researcher, 43(6), 293-303.

Hurley, E., \& Murphy, R. (2015).The development of a new method of idiographic measurement for dynamic assessment intervention. Journal of Pedagogy, 6(1), 43-60.

Jones, I., \& Inglis, M. (2015). The problem of assessing problem solving: Can comparative judgement help?. Educational Studies in Mathematics, 89(3), 337-355.

Karakaya, Z. (2002), Çevirimiçi (On-line) Sınav Sistemi Geliştirilmesi ve Uygulanması Açık ve uzaktan eğitim sempozyumu, 23-25 Mayıs, Eskişehir.

Kearns, J., Kleinert, H., Thurlow, M., Gong, B., \& Quenemoen, R. (2015). Alternate assessments as one measure of teacher effectiveness. Research and Practice for Persons with Severe Disabilities, 40(1), 20-35.

Lau, S., Hong, K., Lau, N., \& Usop, H. (2012). Web-based assessment with number right elimination testing (NRET) scoring for multiple-choice items. The Asia-Pasific Education Researcher, 21(1), 107-116.

Lin, S.S.J., Liu, E.Z.F., \& Yuan, S.M. (2001). Web-based peer assessment: feedback for students with various thinking-styles, Journal of Computer Assisted Learning 17, 420-432.

Milli Eğitim Bakanlığı, (2004). Illköğretim fen ve teknoloji dersi (4-5 Sınıflar Öğretim Programı). Ankara: Devlet Kitapları Basım Evi. 
Milli Eğitim Bakanlı̆̆ı. (2013). Illköğretim kurumları fen bilimler dersi (3, 4, 5, 6, 7 ve 8. sınıflar) ögrretim programı. Ankara: Devlet Kitapları Basım Evi.

Rutkowski, D. ,Rutkowski, L., \& Plucker, J. (2015). Should individual U.S. schools participate in PISA?. Phi Delta Kappan, 96(4), 68-73.

Sabry, K., \& Baldwin, L. (2003). Web-based learning interaction and learning styles, British Journal of Educational Technology, 34(4), 443-454.

Saprıatı, A. \& Zuhaırı, A. (2010).Using computer-based testing as alternative assessment method of student learning in distance education, Turkish Online Journal of Distance Education (TOJDE), 11(2), 161-169.

Varsavsky, C., \& Rayner, G. (2014). Strategies that challenge: Exploring the use of differentiated assessment to challenge high-achieving students in large enrolment undergraduate cohorts. Assessment \& Evaluation in Higher Education, 38(7), 789-802.

Wellman, G.S. (2005). Comparing Learning Style to Performance in On-Line Teaching: Impact of Proctored V. Un-Proctored Testing. Journal of Interactive Online Learning, 4 (1), 20-39.

Wyse, A., \& Albano, A. (2015). Considering the use of general and modified assessment items in computerized adaptive testing.Applied Measurement in Education, 28(2), 156-167.

Yıldırım, A., ve Şimşek, H. (2005). Sosyal bilimlerde nitel araştırma yöntemleri, Güncelleştirilmiş Beşinci Baskı, Seçkin Yayınları, Ankara. 


\section{GENIŞ ÖZET}

Fen Bilimleri Dersi Öğretim Programında yer alan alternatif ölçme ve değerlendirme yaklaşımı öğretmen-öğrenci ve veli işbirliğine dayanmaktadır. Bu nedenle öğretmen, öğrenci ve özellikle velilerin ölçme ve değerlendirme sürecindeki görev ve sorumluluklarının farkında olmaları gerekmektedir. Öğretmen-öğrenci-veli üçgeninde değerlendirme sürecine herhangi birinin katılmaması, ölçme ve değerlendirmenin yeterince etkili yapılamamasına, bir başka ifadeyle ölçme ve değerlendirmenin başarısız olacağı sonucunu ortaya çıkaracaktır.

Öğrencilerin değerlendirme sürecine katılımları akran değerlendirme veya öz değerlendirme şeklinde olabilmektedir. Veliler ise, bu sürece kendileri için hazırlanan öğrencisini değerlendirmede kullanacakları formlar yardımıyla katılmaktadır. Bu formlarla ilgili bazı örnekler fen bilimleri dersi için yayınlanan öğretim programları ve bazı öğretmen kılavuzlarında mevcuttur. Fen Bilimleri Dersi Öğretim Programında, araştırma-sorgulamaya dayalı öğrenme yaklaşımı temel alınmıştır. Bu öğrenme yaklaşımında yer alan çağdaş değerlendirme tekniklerinde, değerlendirme sürecine velilerin katılımının daha fazla olması beklenmektedir (Milli Eğitim Bakanlı̆̆ı [MEB], 2013).

Fen Bilimleri Dersi Öğretim Programının dayandığı yapısalcı, araştırma ve sorgulmaya dayalı yaklaşımda alternatif ölçme ve değerlendirme sürecine velinin daha aktif olarak katılımını sağlayabilmek için web destekli programlar kullanıllanılabilir. Web destekli programların eğitim yaşamında sağladığı avantajlar göz önüne alındığında, alternatif ölçme ve değerlendirme yaklaşımlarının uygulanması ve değerlendirilmesinde de velileri sürece daha fazla katabileceği kaçınılmazdır. Uluslararası alan yazına bakıldığında özelikle e-portfolyo sistemleri, akran değerlendirme, rubrik geliştirme ile ilgili web programların ve web tabanlı programların geliştirilmesi üzerine çalışmaların yürütüldüğü görülmektedir. Bu çalışmalarda alternatif ölçme ve değerlendirme yöntem ve tekniklerinin web tabanlı olarak uygulanabileceği ve bu tür uygulamaların öğrenci ve veliler üzerinde olumlu etkilerinin olduğu görülmüştür.

Alternatif değerlendirme formlarının web ortamında hazırlanması ve uygulanmasına imkân veren bir web tabanlı programın hazırlanması, bu tür değerlendirme formlarını hazırlama, uygulama ve velileri sisteme katma konusunda yeni bir boyut ve bakış açısı getirecektir. Web ortamında hazırlanan eğitim siteleri incelendiğinde genellikle belirli bir dersin belirli bir ünitesi veya konusunun yürütülmesi sırasında kullanılabilecek ortamların hazırlandığı görülmektedir. Ölçme-değerlendirme veya performans değerlendirmenin puanlanması için ölçeklerin hazırlanılmasını ve/veya uygulanmasını hedefleyen bir web ortamının olmadığı dikkat çekmektedir. Araştırmanın bu özgün değeri özellikle ülkemiz araştırmacılarına önemli bilgiler sağlamakla birlikte, velilerin ölçme ve değerlendirme sürecine daha etkili olarak katılmalarına olanak sağlayacaktır.

Dolayısıyla bu çalışma velilerin değerlendirme sürecine ya hiç katılmamaları veya çok az katkıda bulunmalarının sebep olduğu eksikliğin, web destekli ortam ve araçlar yardımıyla ne derecede giderilebileceğinin gösterilmesi açısında önemli olduğu düşünülmektedir. Öğrencileri ve velileri değerlendirme sürecine katabilen, yapılan tüm değerlendirmeleri bir araya getirerek ortalama puanı hesaplayabilen, elde edilen bilgiler ışında geri bildirimin yapılmasına olanak sağlayan web tabanlı bir programın velilerin ihtiyaçlarını ne derecede karşıladığı, kullanabilirliğinin ne düzeyde olduğu ve programın geliştirme sürecinde ne tür değişikliklere ihtiyaç duyulduğunu belirlenmesi gerekmektedir. Bu bağlamda çalışmada velilerin web tabanlı performans değerlendirme programı hakkındaki görüşlerinin incelenmesi amaçlanmıştır.

Bu çalışmada özel durum yöntemi kullanılmıştır. Bu yöntem, araştırılan problemin bir yönünün derinlemesine ve kısa sürede çalışılmasına olanak sağlamaktadır. Yöntem doğası gereği, bir problemin özel bir durumu üzerine yoğunlaşma fırsatı verirken, farklı veri toplama tekniklerinin bir arada kullanılmasına da olanak tanır. Çalışma, Trabzon il merkezinde 2014-2015 eğitim öğretim dönemi güz döneminde 109 K571 kodlu TÜBiTAK projesi kapsamındaki 300 veli ile yürütülmüştür. 300 veliye anket uygulanırken, bu velilerden 10 tanesi ile yüz yüze görüşmeler yapılmıştır. Örneklemi oluşturan velilerden 117 'si kadın, 183'ü ise erkektir. Mülakat yapılan velilerin seçiminde, web tabanlı performans değerlendirme programını aktif olarak kullanma ölçütleri dikkate alınmıştır. Çalışmaya katılan velilere iki haftalık hizmet içi kursu verilmiştir. 
Çalışmada veri toplama aracı olarak anket ve yarı yapılandırılmış mülakat kullanılmıştır. Ankette yer alan maddeler dört başlık altında toplanmıştır. Bu başlıklar; web tabanlı programın işlevsel özellikleri, web tabanlı programın teknik özellikleri, web tabanlı programın kullanımının sağladığı avantajları ve web tabanlı programın kullanımında karşılaşılan sorunlar şeklinde sıralanmıştır. Mülakatlar, katılımcıların uygun olduğu bir zamanda işyerlerinde veya evlerinde gerçekleştirilmiştir. Anket ile elde edilen veriler frekans ve yüzde olarak hesaplanmış ve tablolar halinde sunulurken, görüşmelerde elde edilen veriler içerik ve betimsel analiz yardımıyla analiz edilmiştir. Çalışmaya katılan velilerin büyük çoğunluğu; öğrencilerinin nasıl değerlendirildiği, ölçme aracı olarak ne tür performansların yer aldığını ve bu çalışmalardan hangi notlar aldıklarını görebilmelerinde oldukça memnun oldukları görülmüştür.

Elde edilen bulgular incelendiğinde, uygulama sonucunda velilerin web tabanlı performans değerlendirme programı hakkında oldukça olumlu düşüncelere sahip oldukları görülmüştür. Bunun yanında çalışmaya katılan bazı veliler ise; web tabanlı performans değerlendirme programının uygulama süreci, tasarımı ve kullanabilirliği konusunda bazı eksikliklerin olduğunu belirtmişler ve bu eksikliklerin giderilmesi noktasında önerilerde bulunmuşlardır. Ölçme ve değerlendirme sürecinin web tabanlı program yardımıyla desteklenmesi ve bu sürece paydaşları olan öğretmen, öğrenci ve velilerin katılması eğitim-öğretim döneminin sonunda daha adaletli bir değer yargısının oluşmasında etkili olduğu çalışma sonunda ortaya çıkmıştır. Ancak çalışmanın oldukça kısıtlı bir veli katılımıyla yürütülmüş olması bu yönündeki görüşleri tam olarak yansıtmada yetersiz kalmıştır. Bu web tabanlı programın daha geniş örneklem üzerinde uygulanması bu yöndeki görüşlerin daha net ortaya çıkarılmasını sağlayacaktır. Velilerin ölçme ve değerlendirme sürecinde rol oynamalarının onlar açısından önemini daha açık şekilde belirlenmeli program geliştirme sürecinde de katkılar sağlayacaktır.

Çalışmaya katılan velilerin büyük çoğunluğu öğrencilerinin nasıl değerlendirildiği, ölçme aracı olarak ne tür performansların yer aldığını ve bu çalışmalardan hangi notlar aldıklarını web tabanlı program sayesinde hızlı ve güvenilir bir şekilde görebiliyor olsalar da bazı veliler hızla yazılımı etkili bir şekilde kullanamadıkları belirtmişlerdir. Bu konuda velilerin teknoloji okuryazarlıkları ve eğitimleri daha da önem kazandığı ortaya çıkmıştır. Velilerin web tabanlı programı neden etkili bir şekilde kullanamadıkları belirlenmeli ve veli eğitimine yönelik hazırlanan eğitim materyali gözden geçirilerek daha çok velinin web tabanlı programları etkili bir şekilde kullanılabilecek hale getirilmelidir. 